\title{
Better Utilisation of Bottom Ash in Coal Fired Thermal Power Station
}

\author{
J.Kenny Fernando, T.P. Meikandaan, M. Hemapriya
}

\begin{abstract}
In coal fired Thermal Power Station Bottom Ash is collected in Large quantities and stored in dykes.This project is done to convert the Bottom Ash in to a useful product which has good Adsorption Capacity of Hardness Causing Salts in hard water. This Bottom Ash is fused with $\mathrm{NaOH}$ and then Hydro Thermal synthesis was done and the extract was mixed with Sodium Aluminate and synthesis was done. The molarities of $\mathrm{NaOH}$, temperature and duration was varied and synthesis was done. The synthesized product was tested for adsorption of Ca ions from Hard Water and found that it adsorbed the Ca ions.
\end{abstract}

Key Word: Sodium Hydroxide, Sodium Aluminate, Adsorption, Hydro Thermal Synthesis.

\section{INTRODUCTION}

In coal fired Thermal Power Station in India lot of Ash is generated. Out of this Fly is finding lot of application and hence it is utilized in more quantity. But the Bottom Ash is not used and it is stored in dykes. The maintenance of the dykes is a great challenge and involves huge amount of money. There is a lot of environmental challenge due to leaching of toxic materials and breach of bunds. In order to prevent this problem this project is taken to convert the Bottom Ash in to useful product .The sample of Bottom Ash was taken from North Chennai Thermal Power Station for doing this project work.

Revised Manuscript Received on July 22, 2019.

J.Kenny Fernando, Student, Department of Civil Engineering, Bharath Institute Of Higher Education and Research, Chennai, Tamil Nadu. kennyfernandoj@gmail.com

T.P. Meikandaan, Associate Professor, Department of Civil Engineering, Bharath Institute Of Higher Education and Research, Chennai, Tamil Nadu. ganga_meik@yahoo.co.in

M.Hemapriya Assistant Professor, Department of Civil Engineering, Bharath Institute Of Higher Education and Research, Chennai, Tamil Nadu. meihemapriya@gmail.com

\section{MATERIALS AND METHODS}

\section{A. Materials}

The materials used for this experiment are $2 \mathrm{~kg}$ of bottom ash collected from the Ash Dyke of North Chennai Thermal Power Station. Sodium Chloride, Sodium Hydroxide Pellets, Calcium Chloride Fused, Magnesium Sulphate Heptahydrate, Sodium AluminateEquipments used were Muffle furnace,Air Oven ,Electronic Weighing Balance,Magnetic stirrer with hot plate.Ceramic Crucibles.

\section{EXPERIMENTAL PROCEDURE}

\section{A. Sample collection}

$2 \mathrm{~kg}$ of bottom ash collected from the Ash Dyke of North Chennai Thermal Power Station by using poclain in

polythene bags which were clean and dry. The samples were taken as two one kg bags.

\section{B. Sample Preparation}

The sample was air dried and grinded to a powder form, it was then dried in a oven at $105 \mathrm{C}$ for one hour.

\section{Extraction}

The sample was tested for $\mathrm{pH}$ and it was found to be 9 .Then the sample was mixed with Sodium Hydroxide and heated in a muffle furnace at $700 \mathrm{C}$ for one hour.

The fused sample is mixed with D.M. water and heated to $60 \mathrm{C}$ with continuous stirring in a magnetic stirrer for one hour.Then the liquid was decanted and the sediments were removed. The decanted liquid was mixed with Sodium aluminate and stirred with magnetic stirrer.Then it was heated in a oven at $105 \mathrm{C}$ for 24 hours. The product obtained was washed with D.M water several times till the $\mathrm{pH}$ gets reduced to 8 . Then it is dried in an oven at $105 \mathrm{C}$ for $2 \mathrm{hrs}$.

\section{Testing}

The extracted powder is tested for adsorption of hardness causing calcium salts and then the product is filtered. Calcium Chloride of 400 PPM is prepared and $50 \mathrm{ml}$ of the solution is taken and mixed with $0.5 \mathrm{gm}$ of the synthesized powder and kept in amagnetic stirrer for 2 
hrs . Then the solution is filtered in a filter paper the filtered liquid is tested for hardness and all the calcium was absorbed. were tried out. There are a lot of other possibilities which can be tried out by varying the Molarity of $\mathrm{NaoH}$ and the concentration of Sodium Aluminate .

\section{RESULTS}

\begin{tabular}{|l|l|l|l|}
\hline $\begin{array}{l}\text { SL } \\
\text { No }\end{array}$ & Description & $\begin{array}{l}\text { NCTPS } \\
\text { dyke }\end{array}$ & $\begin{array}{l}\text { NCTPS } \\
\text { Inside }\end{array}$ \\
\hline 1 & $\begin{array}{l}\text { Insoluble Residue } \\
\%\end{array}$ & 93.57 & 93.67 \\
\hline 2 & $\begin{array}{l}\text { Loss on Ignition } \\
\%\end{array}$ & 4.45 & 4.10 \\
\hline 3 & $\mathrm{SO}_{3}$ & 0.31 & 0.33 \\
\hline 4 & $\mathrm{SiO}_{2}$ & 60.38 & 60.17 \\
\hline 5 & $\mathrm{Al}_{2} \mathrm{O}_{3}$ & 26.59 & 27.04 \\
\hline 6 & $\mathrm{Fe}_{2} \mathrm{O}_{3}$ & 4.26 & 4.15 \\
\hline 7 & $\mathrm{CaO}^{\mathrm{MgO}}$ & 1.70 & 1.58 \\
\hline 8 & $\mathrm{MgQ}$ & 1.01 & 1.09 \\
\hline 9 & $\mathrm{Moisture}$ & 18 & 20 \\
\hline 10 & $\mathrm{Blaine} \mathrm{M} 2 / \mathrm{Kg}$ & 84 & 60 \\
\hline 11 & $90 \mathrm{MIC}$ & 5.08 & 4.64 \\
\hline 12 & $45 \mathrm{MIC}$ & 94.92 & 95.36 \\
\hline 13 & LR & 0.2 & 0.25 \\
\hline
\end{tabular}

\section{RESULTS AND DISCUSSION}

Use Coal Bottom Ash collected from Boiler Bottom was tested for $\mathrm{pH}$ and found to be slightly acidic. Then it was fused at $700 \mathrm{C}$ for 1 hour and cooled and then tested for $\mathrm{pH}$ then it was found to be basic. Then the sample was fused without the removal of iron and with addition of $0.1 \mathrm{~N}$ of $\mathrm{NaoH}$ and tested for $\mathrm{CEC}$ which yielded very low CEC i.e. 2 meq/L.

Then the sample was fused with $0.1 \quad \mathrm{~N}$ of $\mathrm{NaOH}$ with the removal of iron and tested for CEC which yielded a value of $20 \mathrm{meq} / \mathrm{L}$.

Then the sample was fused with sodium aluminate without the addition of $\mathrm{NaOH}$ and tested for $\mathrm{CEC}$ which yielded a value of $20 \mathrm{meq} / \mathrm{L}$.

From the above tests the effect of removal of iron and addition of $\mathrm{NaOH}$ was understood. Moreover when the sample was dried and then ground a paste like substance was formed which was dried and then the various parameters like temperature and time were tried out. There are a lot of other possibilities which can be tried out by varying the Molarity of $\mathrm{NaOH}$ and the concentration of Sodium Aluminate .

\begin{tabular}{|l|l|l|}
\hline $\begin{array}{l}\text { Sl } \\
\text { no }\end{array}$ & Description & Value in \% \\
\hline 1 & $\mathrm{SiO}_{2}$ & 51.17 \\
\hline 2 & $\mathrm{Al}_{2} \mathrm{O}_{3}$ & 38.7 \\
\hline 3 & $\mathrm{Fe}_{2} \mathrm{O}_{3}$ & 8.99 \\
\hline 4 & $\mathrm{CaO}$ & 0.14 \\
\hline 5 & $\mathrm{MgQ}$ & 0.14 \\
\hline
\end{tabular}

\section{CONCLUSION}

Because From the above process it was concluded that fusion of the sample with Sodium Hydroxide followed by hydrothermal synthesis was optimum as per the facilities available within the limits of our capacity. The $\mathrm{Si} / \mathrm{Al}$ ratio has a deciding factor. More over the hydro thermal synthesis has a very effective part. The synthesized product was very effective in adsorbing the hardness causing salts like $\mathrm{Ca}$ and $\mathrm{Mg}$.Ca of 440ppm was completely absorbed in $0.5 \mathrm{gms}$ of the synthesized powder.

\section{REFERENCES}

1. Iyappan L., Dayakar P., Identification of landslide prone zone for coonoortalukusing spatial technology, International Journal of Applied Engineering Research,V-9,I-22,PP-5724-5732,Y-2014.

2. Kumar J., Sathish Kumar K., Dayakar P.,Effect of microsilica on high strength concrete, International Journal of Applied Engineering Research,V-9,I-22,PP-5427-5432,Y-2014.

3. Dayakar P., Vijay Ruthrapathi G., Prakesh J., Management of bio-medical waste, International Journal of Applied Engineering Research,V-9,I-22,PP-5518-5526,Y-2014.

4. Swaminathan N., Dayakar P., Resource optimization in construction project, International Journal of Applied Engineering Research,V-9,I-22,PP-5546-5551,Y-2014.

5. Venkat Raman K., Dayakar P., Raju K.V.B.,An experimental study on effect of cone diameters in penetration test on sandy soil, International Journal of Civil Engineering and Technology,V-8,I-8,PP-1581-1588,Y-2017.

6. Saritha B., Chockalingam M.P.,Photodradation of malachite green DYE using TIO2/activated carbon composite,International Journal of Civil Engineering and Technology,V-8,I-8,PP-156-163,Y-2017

7. Shendge R.B., Chockalingam M.P., Saritha B., Ambica A.,Swat modelling for sediment yield: A case study of Ujjani reservoir in Maharashtra, India,International Journal of Civil Engineering and Technology,V-9,I-1,PP-245-252,Y-2018

8. Chockalingam M.P., Balamurgan V.,Modernisation of an existing urban road-sector in Chennai, a case study report,International Journal of Civil Engineering and Technology,V-8,I-8,PP-1457-1467,Y-2017

9. Saritha B., Chockalingam M.P.,Adsorption study on removal of basic dye by modified coconut shell adsorbent, International Journal of Civil Engineering and Technology,V-8,I-8,PP-1370-1374,Y-2017

10. Saritha B., Chockalingam M.P.,Adsorptive removal of heavy metal chromium from aqueous medium using modified natural adsorbent,International Journal of Civil Engineering and Technology,V-8,I-8,PP-1382-1387,Y-2017

11. Chockalingam M.P., Palanivelraja S.,Retrospective analysis of a theoretical model used for forecasting future air quality near the north Chennai thermal power plant,International Journal of Civil Engineering and Technology,V-8,I-8,PP-1457-1467,Y-2017

12. Saritha B., Chockalingam M.P.,Photodegradation of methylene blue dye in aqueous medium by $\mathrm{Fe}-\mathrm{AC} / \mathrm{TiO} 2$ Composite,Nature Environment and Pollution Technology,V-17,I-4,PP-1259-1265,Y-2018

13. Shendge R.B., Chockalingam M.P., Kaviya B., Ambica A.,Estimates of potential evapotranspiration rates by three methods in upper Bhima Basin, In Maharashtra, India,International Journal of Civil Engineering and Technology,V-9,I-2,PP-475-480,Y-2018

14. Shendge R.B., Chockalingam M.P.,The soil and water assessment tool for Ujjani Reservoir,International Journal of Mechanical Engineering and Technology,V-9,I-2,PP-354-359,Y-2018

15. Shendge R.B., Chockalingam M.P.,A review on soil and water assessment tool,International Journal of Mechanical Engineering and Technology,V-9,I-2,PP-347-353,Y-2018

16. Sachithanandam P., Meikandaan T.P., Srividya T.,Steel framed multi storey residential building analysis and design,International Journal of Applied Engineering Research,V-9,I-22,PP-5527-5529,Y-2014

17. Meikandaan T.P., Ramachandra Murthy A.,Study of damaged RC beams repaired by bonding of CFRP laminates,International Journal of Civil Engineering and Technology,V-8,I-2,PP-470-486,Y-2017

18. Meikandaan T.P., Ramachandra Murthy A.,Retrofittng of reinforced concrete beams using GFRP overlays,International Journal of Civil Engineering and Technology,V-8,I-2,PP-423-439,Y-2017

19. Meikandaan T.P., Ramachandra Murthy A.,Flexural behaviour of RC beam wrapped with GFRP sheets,International Journal of Civil

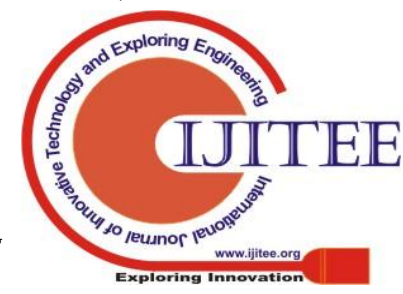


Engineering and Technology,V-8,I-2,PP-452-469,Y-2017

20. Meikandaan T.P., Murthy A.R.,Experimental study on strengthening of rc beams using glass Fiber,International Journal of Civil Engineering and Technology,V-9,I-11,PP-959-965,Y-2018

21. Meikandaan T.P., Hemapriya M.,Use of glass FRP sheets as external flexural reinforcement in RCC Beam,International Journal of Civil Engineering and Technology,V-8,I-8,PP-1485-1501,Y-2017

22. Saraswathy R., Saritha B.,Planning of integrated satellite township at Thirumazhisai,International Journal of Applied Engineering Research,V-9,I-22,PP-5558-5560,Y-2014

23. Saritha B., Ilayaraja K., Eqyaabal Z.,Geo textiles and geo synthetics for soil reinforcement,International Journal of Applied Engineering Research,V-9,I-22,PP-5533-5536,Y-2014

24. Ambica A., Saritha B., Changring G., Singh N B., Rajen M., Salman Md.,Analysis of groundwater quality in and around Tambaram taluk, Kancheepuram district,International Journal of Civil Engineering and Technology,V-8,I-8,PP-1362-1369,Y-2017

25. Arunya A., Sarayu K., Ramachandra Murthy A., Iyer N.R.,Enhancement of durability properties of bioconcrete incorporated with nano silica,International Journal of Civil Engineering and Technology,V-8,I-8,PP-1388-1394,Y-2017

26. Ilayaraja K., Krishnamurthy R.R., Jayaprakash M., Velmurugan P.M., Muthuraj S.,Characterization of the 26 December 2004 tsunami deposits in Andaman Islands (Bay of Bengal, India),Environmental Earth Sciences, V-66,I-8,PP-2459-2476,Y-2012

27. Ilayaraja K.,Morphometric parameters of micro watershed in Paravanar sub-basin, Cuddalore District,International Journal of Civil Engineering and Technology,V-8,I-8,PP-1444-1449,Y-2017

28. Ilayaraja K., Singh R.K., Rana N., Chauhan R., Sutradhar N.,Site suitability assessment for residential areas in south Chennai region using remote sensing and GIS techniques, International Journal of Civil Engineering and Technology,V-8,I-8,PP-1468-1475,Y-2017

29. Ilayaraja K., Reza W., Kumar V., Paul S., Chowdhary R.,Estimation of land surface temperature of Chennai metropolitan area using Landsat images,International Journal of Civil Engineering and Technology,V-8,I-8,PP-1450-1456,Y-2017

30. Chitra R.,Experimental study on beam using steel fiber and latex,International Journal of Civil Engineering and Technology,V-8,I-8,PP-1395-1403,Y-2017

31. Chitra R.,Analysis of traffic and management at Kovilambakkam intersection,International Journal of Civil Engineering and Technology,V-8,I-8,PP-1433-1443,Y-2017

32. Aswathy M.,Experimental study on light weight foamed concrete,International Journal of Civil Engineering and Technology,V-8,I-8,PP-1404-1412,Y-2017

33. Aswathy M.,Wastewater treatment using constructed wetland with water lettuce (Eichornia Crasipies),International Journal of Civil Engineering and Technology,V-8,I-8,PP-1413-1421,Y-2017

34. Kiruthiga K., Anandh K.S., Gunasekaran K, Assessment of influencing factors on improving effectiveness and productivity of construction engineers, 2015, International Journal of Applied Engineering Research, V - 10,I -17,p -13849-13854.

\section{AUTHORS PROFILE}

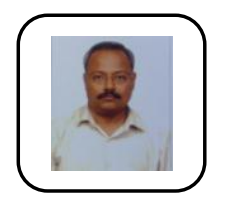

J.Kenny Fernando, student, Department of Civil Engineering, Bharath Institute of Higher Education and Research, Chennai, India

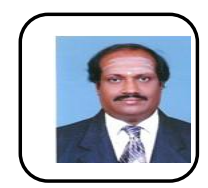

T.P. Meikandaan,Associate professor, Department of Civil Engineering, Bharath Institute of Higher Education and Research, Chennai, India

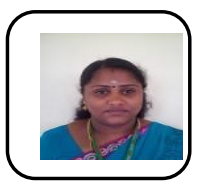

M.Hemapriya Assistant professor Department of Civil Engineering, Bharath Institute of Higher Education and Research, Chennai, India 